5. Седюк І. О. Ігрова логіка у фортепіанних дуетах В. Птушкіна. Міжнародний вісник: культурологія, філологія, музикознавство. 2017. Вип. ІІ(9). С. 250-255.

6. Щербаков Ю.В. Жанровий генезис та стильові модифікації сюїти танцювального типу для двоклавірного дуету: виконавський аспект : автореф. дис. на здобуття наук. ступеня канд. мистецтвознав. : 17.00.03. Одеса, 2015. 18 с.

7. Яценко Е. В. Любите живопись, поэты. Экфрасис как художественно-мировоззренческая модель. Вопросы фиилософии: науч.-теор. журнал. 2011. № 11. С. 47-57.

\title{
References
}

1. Antonova E.G., \& Kudryavtseva I.V. (2012). «Six Meditations» for flute and bayan by V. Zubitsky: On the question of the incarnation of images of reflections in musical art. Musical art, 12, 144-155 [in Russian].

2. Zaitseva M.L. (22.10.2014). The phenomenon of synesthesia in the art of postmodernism. Psychologist, Vol. 5. Retrieved from: http://e-notabene.ru/psp/article_13379.html

3. Kodyeva O.P. (2009). Pictorial in conceptual and categorical system of culturology. Extended abstract of doctor's thesis. Kyiv [in Ukrainian].

4. Mankovskaya N.B. (1995). «Paris with snakes» (introduction to the aesthetics of postmodernism). Moscow: IFRAN [in Russian].

5. Sedyuk I.O. (2017). The game logic in piano duos by V. Ptushkin. International Journal: Culturology, Philology, Musicology, II(9), 250-255 [in Ukrainian].

6. Shcherbakov Yu.V. (2015). Genre genesis and stylistic modifications of dance-type suites for double-clavier duet: performance aspect. Extended abstract of candidate's thesis. Odesa [in Ukrainian].

7. Yatsenko E.V. (2011). Love painting, poets. Ekphrasis as an artistic and ideological model. Philosophy issues, 11, 47-57 [in Russian].

Стаття надійшла до редакції 16.08.2018 p.

Удк 7.097:316.74:140.8-053.67

\author{
Kravchenko Tetyana \\ Candidate of Art Studies, \\ Senior Lecturer of the Kyiv National \\ I. K. Karpenko-Kary Theatre, Cinema \\ and Television University \\ ORCID 0000-0003-1208-6801
}

\section{SOCIO-CULTURAL VALUE OF TELEVISION AS A SCREEN FORM OF ART IN SHAPING THE OUTLOOK OF A YOUNG SPECTATOR}

The purpose of the article is to investigate the influence of television on a child. The methodology of the research consists in application of general scientific and specific scientific methods: analytical - for the study of philosophical, cultural, literary literature on the topic, the disclosure of the essence of television as a socio-cultural phenomenon; theoretical - to generalize the theoretical positions and observations on the nature of the influence of television broadcasting on television audience; historical - to systematize information on the history of the development of television broadcasting and floating; comparative - to determine the general and specific features of the programs of modern television in different countries of the world. Scientific novelty consists in the study of television as an on-screen art tool that can influence, in particular, the outlook of the young viewer and shape the outlook of a new generation of screen culture consumers. Television is a young form of art, so the means of its influence on a viewer are in the stage of development and improvement. One of them is the phenomenon of absolute realism. But, at the same time, television in its daily interpretation of reality predicts a certain emotional and psychological effect in the audience, having in its basis a creative idea that re-integrates the whole process of communication. The most noticeable and visible this effect is in the cell of a young spectator, since it is the children, who are open to perceiving new information and do not have a critical perception of reality. With the advent of new forms of art, the person himself, and his means to perceive the world around him, has changed. There was a new generation of heat consumers in the world. That is why it is important to find out what a young spectator watches today and what images and emotions these television broadcasts bring out. Conclusions. Television is an independent form of screen art that uses visual images as its language. Today, virtually the entire broadcasting network carries some kind of messages, on which the viewer is reacting delicately. The system of values that is born during this dialogue has an important information component, which is crucial for the further development of communication. Aesthetic codes addressed to the audience are not just a tongue of television. They are a peculiar clue to the viewer's self-awareness with the reality that gives him television. Television becomes the reality that the young spectator perceives without critical analysis and rethinking. However, one should not accept TV as a universal evil. The super-fast present, puts certain conditions of informatization of society, giving birth to a new culture - this is television. In Ukraine, this culture is actively developing. However, today there is an acute shortage of educational and science-popular programs of good quality that younger generation needs. And children's products for preschoolers of their own production are practically absent.

Key words: television; influence; children; advertising.

(C) Kravchenko T., 2018 
Кравченко Тетяна Олександрівна, кандидат мистецтвознавства, старший викладач Київського національного університету театру, кіно і телебачення ім. І.К. Карпенка-Карого

Соціокультурна цінність телебачення як екранного засобу мистецтва у формуванні світогляду юного глядача

Мета статті - дослідити вплив телебачення, як екранного засобу мистецтва на дитину. Методологія дослідження - застосовано загальнонаукові та конкретнонаукові методи: аналітичний - для вивчення фрілософської, культурологічної, мистецтвознавчої літератури з теми, розкриття сутності телебачення, як соціокультурного френомена; теоретичний - для узагальнення теоретичних положень і спостережень щодо природи впливу телевізійного мовлення на телеаудиторію; історичний - для систематизації відомостей з історію розвитку телевізійного мовлення і пливу; порівняльний - для визначення загальних та особливих ознак в програмах сучасного телебачення різних країн світу. Наукова новизна полягає в дослідженні телебачення, як екранного засобу мистецтва, що здатне впливати зокрема і на світогляд юного глядача та фрормувати світогляд нового покоління споживачів екранної культури. Телебачення - молодий вид мистецтва, тому засоби його впливу на глядача перебувають в стадії розвитку й вдосконалення. Одна з унікальних його якостей - феномен абсолютної реалістичності. Але, разом із тим телебачення в своїй повсякденній інтерпретації реальності прогнозує певний емоційно-психологічний ефект у аудиторії, маючи в своїй основі творчий задум, що перевтілює весь процес комунікації. Найбільш відчутний і видимий цей ефект в осередку юного глядача, адже саме діти відкриті для сприйняття нової інформації і не мають критичного сприйняття реальності. 3 появою нових видів мистецтва змінилась і сама людина, її засіб сприймати навколишній світ. З'явилось нове покоління теплоспоживачів світу. Саме тому важливо з'ясувати що саме дивиться сьогодні юний глядач і які образи та емоції викликають у нього ці телеперегляди. Висновки. Телебачення - $\epsilon$ самостійною формою екранного мистецтва, що використовує в якості своєї мови візуальні образи. Сьогодні практично вся мережа мовлення несе в собі певні послання на які діже тонко реагує телеглядач. Система цінностей, що народжується під час цього діалогу, має важливу інформаційну складову, що є визначальною у подальшому розвитку комунікації. Естетичні коди, що адресовані аудиторії, $є$ не просто мовою телебачення. Вони є своєрідним ключем для самоусвідомлення глядача із тією реальністю, що надає йому телебачення. Телебачення і стає тією реальністю, що саме юний глядач сприймає без критичного аналізу та переосмислення. Проте, не слід сприймати ТБ лише як вселенське зло. Надшвидке сьогодення , ставить певні умови інформатизації суспільства, народжуючи нову культуру - телевізійну. В Україні ця культура активно розвивається. Проте, сьогодні відчувається гостра нестача освітніх та науково-популярних програм хорошої якості, який потребує підростаюче покоління. А дитяча продукція для дошкільнят власного виробництва - практично відсутня.

Ключові слова: телебачення; вплив; діти; реклама.

Кравченко Татьяна Александровна, кандидат искусствоведения, старший преподаватель Киевского национального университета театра кино и телевидения им. И.К. Карпенко-Карого

Социокультурная значимость телевидения как экранного вида искусств в формировании мировоззрения юного зрителя

Цель статьи - изучить воздействие телевидения, как экранного вида искусств на ребенка. Методология исследования - использованы общенаучные и конкретно-научные методы: аналитический для изучения философской, культурологической, искусствоведческой литературы по теме раскрытия сущности телевидения, как социо-культурного феномена; теоретический - для обобщения теоретических положений и наблюдений относительно природы воздействия телевизионного вещания; исторический - для систематизации сведений по истории развития телевизионного вещания и воздействия; сравнительный - для определения общих и индивидуальных качеств в программах современного телевидения разных стран мира . Научная новизна заключается в исследовании телевидения, как экранного вида искусств, способного влиять в том числе и на мировоззрение юного зрителя и формировать мировоззрение нового поколения потребителей экранной культуры. Телевидение молодой вид искусства, поэтому средства его воздействия на зрителя находятся в стадии развития и совершенствования. Одно из важнейших его качеств - феномен абсолютной реалистичности. Но, вместе с тем телевидения В своей повседневной интерпретации реальности прогнозирует определенный эмоциональнопсихологический эффеект в аудитории, имея в своей основе творческий замысел, преображает весь процесс коммуникации. Наиболее подвержен этому эффекту юный зритель, ведь именно дети открыты для восприятия новой информации и не обладают критическим переосмыслением реальности. С появлением новых видов искусства изменилась и сам человек, его средство воспринимать окружающий мир. Появилось новое поколение теле-потребителей мира. Именно поэтому важно выяснить что именно смотрит сегодня юный зритель, какие образы и какие эмоции вызывают у него эти телепросмотры. Выводы. Телевидение - является самостоятельной формой экранного искусства, которая использует в качестве своего языка визуальные образы. Сегодня практически вся сеть вещания несет в себе определенные послания на которые тонко реагирует телезритель. Этот диалог порождает определенную систему ценностей и имеет важную информационную составляющую, что является определяющим в развитии дальнейшей коммуникации. Эстетические коды, адресованные аудитории, являются не просто языком телевидения. Они - своеобразный ключ для самоосознания зрителя с той реальностью, которую преподносит ему телевидения. Само телевидение и становится той реальностью, которую юный зритель воспринимает без критического анализа и переосмысления. Однако, не следует воспринимать ТВ только как вселенское зло. Сверхбыстрое настоящее ставит определенные условия информатизации общества, рождая новую культуру - телевизионную. В Украине эта культура активно развивается. Однако, сегодня ощущается острая нехватка образовательных и научно-популярных программ хорошего качества. Именно в них нуждается подрастающее поколение. А современная детская продукция для дошкольников собственного производства - практически отсутствует.

Ключевые слова: телевидение; влияние; дети; реклама. 
Summary. Twentieth century was the first in the human history, when the main results were obtained after use of influence of technology on massive consciousness, while the people did not feel this influence and acted, as if on their own accord. Television can serve as a similar weapon. Today we can observe second generation of people, who group up in the television era.

Today parents increasingly often leave their children to TV, as it serves as a convenient and cheap entertainment tool. And while family is busy with chores, TV communicates with the child longer and more often than family, teachers or friends.

Modern TV competing for attention of its owners and for commercial purposes and it is ready to put on air low quality production, catering for primitive human instincts. Meanwhile, children do not have critical perception of reality and TV events are perceived as an example to follow. However, some TV production is harmful for child's development.

Modern Ukrainian TV acutely requires reform and strengthened control measures both from authorities and from users themselves. Absence of educational and popular science programs of good quality is felt acutely. There are practically no channels for children or programs for preschoolers. Meanwhile, new, fastpaced society dictates new environment for life of modern people with TV as integral element - an uninterruptible audio visual source for obtaining information, education and entertainment. Technical capacity of TV and its weight in the society are growing with time. As a result, research of integrating, cultural and educational aspects of television in modern conditions gain particular actuality.

Problem statement: Today television due to its audiovisual capacity is the most popular, and thus, most influential media. One of the main functions of television is educational. However, informative substance of the modern Ukrainian television today very often is a result of commercial, and not viewer's needs.

Purpose of this article is to research means and opportunities for influence on the viewer, a child in particular, as children are more susceptible to influence than adults.

Analysis of the latest publications and research. Educational function of television and its educative influence on a viewer is researched by O. R. Samartsev. Studying audience, its psychological peculiarities and how hot television influences it are studied in the works of V.A. Yadov, B. G. Ananyev, B.M. Firsov, V.S. Korobeynikov, L. M. Fedotova. In Ukrainian historiography and culture studies there is a number of researches on establishment and development of Ukrainian television and its influence on audience (U. V. Usenko), as a means of mass communication in the context of its role in forming public opinion of the mega audience (V. Dyachuk, I. Pobiedonostsev), sociocultural essence, of information space, state and problems of its influence on mass audience (O.V. Bunkivska), from the point of psychological and pedagogical channeling (S. Kuzmenko, O. Terehova) and others.

Main results of the research. Television today serves as a powerful instrument of influence on masses. No one using TV can escape from endless information flow from blue screens. From the moment of birth human beings strive to become members of society. This supra biological need [12, 21].

In the modern fast paced society television became an integral element of human life, its connection bridge to the community. Every fifteen years information in the world is doubled, therefore, the need of people to obtain it faster is increasing. Television became a powerful inconspicuous weapon, which is able to change behavior and consciousness of an individual. According to Russian scientist O. R. Samartsev: "Technical progress generates new definitions: evolution of computers and the consciousness is withstanding considerable information pressure, related to avalanche of new scientific and technological ideas." [9, 3]

Society, as O. R. Samartsev indicates, exists in the environment of political, national and financial gap. The scientist predicts, that it is this factor that will be defining the social development. Integrating the modern globalized society with the modern communication media elevates the meaning of television as a factor for forming and studying of the institute of public opinion. This is implemented through stereotypes of particular TV language - kaleidoscope of advertizing images, news blocks, thematic talk shows etc.

Today numerous institutes studying the influence of television on masses, its capacity and functions began to emerge. One of the main functions of television is education, which is directly linked to educative.

Various TV channels are actively trying to educate "their own viewer". At the time, B. G. Ananyev has observed that the main driving force of humanity is "motivation". [1, 87]

TV channels today are actively motivating their viewers. The most sophisticated tricks, advertizing catches and psychological bombs are being used, called to capture our attention. Sometimes this leads to tragic results. A loud scandal at the end of the year before last has shaken Japan. 12 Channel was broadcasting occasional series of the popular amongst Japanese kids cartoon "Pokemon" (pocket monsters). Episodes name was "Firing range of the computer warrior". [13]

Poorly drawn characters (copies of the monsters to the video game by "Nintendo") were fighting each other trying to get into the computer. The screen flickered with red stains - flashes of some sort of vaccine explosion, which is supposed to kill computer viruses. Electric yellow rat "Pikachu", looking more like a squirrel have sparked with his eyes...! That very moment hundreds of children, who were watching the cartoon fainted. Many experienced nausea, convulsions, temporary paralysis of breathing.

Panic kicked in among viewers. The fear was strengthened by a strange coincidence - children fainted immediately after cartoon bomb exploded. Symptoms were really similar to the effect of some sort of psychotropic weapon. 640 children have turned to hospital. Over 100 were hospitalized. Scandal made by 
parents of these children compelled doctors to admit that they are aware about effect of photo epilepsy, when a combination of certain frequency of shimmering of the frames, brightness of the picture and color range may cause an artificial seizure. Unfortunately, these combinations (intuitively or sometimes purposefully) are used by authors of some TV clips, as the influence on viewer become stronger. In Japan the dangerous cartoon was banned for 3 years. Cartoon about pokemons was prohibited also in France and the USA. Meanwhile, In Ukraine this cartoon is being broadcasted without any barriers by TV Channel Inter!

Russian doctors have come to a conclusion that this cartoon has a degrading effect on a child. Children of younger age, who became Pokemon's fans start falling behind in their development, their performance at school deteriorates.

Similar pokemons, creatures of unclear origin and gender, but necessarily mean and stupid, one can every day observe at our TV screens. Cartoons of this sort do no have a distinct plot and their characters are either almost speechless monsters, created by artist's imagination, with more or less enthusiasm are fighting among themselves. [3, 48]

Children are extremely sensitive to acquiring new information and unlike adults they do not have critical assessment. Type of behavior, language, appearance, relations between cartoon or movie characters the child perceives as standard ones and subconsciously starts to copy them.

Recently I asked children from the kindergarten who is the favorite cartoon character. Almost all of them responded: "Tom (from the Walt Disney cartoon), because he hits Jerry", and out of local cartoons the Fox turned out to be the favorite one, "because she eats Kolobok".

Today television is raising in children cruelty, aggression and undue familiarity. Lengthy rest near TV screen has considerable impact on health. Even after 3 hours spent near TV considerably decrease the volume of operative memory, slowing down the speed of thinking. Watching television by children under 7 years old should not exceed 6-7 hours per week, children between 7 and 12 years old -10 hours. The conclusions were made by Russian scientist of the "Institute of applied research". They have established that excessive watching events on the blue screen has a harmful impact on health. [8]

"Emission from TV screen, even if it does not exceed sanitary standards, has cumulative effect and during unlimited sitting in front of TV has a negative impact on immunity system, blood formation etc. Shimmering of bright color spots has negative impact on visual apparatus as a whole (not only on eyes), functioning of heart and brain, because frequency of shimmering (or better say, some components of spatiotemporal spectrum of these fluctuations) can and do coincide with the frequency of heart oscillation and electric oscillation that accompany activity of human heart and brain. Oscillatory resonance constitutes a particular danger". [3, 18]

Duration of watching of TV programs should not exceed 2 hours for adult and half an hour for a small child.

TV programs full of advertising captions constitute a particular danger to the health of a child. Advertisements have to quickly capture attention of the larger audience and to encourage them to buy particular product.

Therefore, technical instruments of advertisements (composition of a frame, lighting, sound, tempo and rhythm, relevant composition) are very powerful, hence, the burden on psyche of the viewer increases. Advertisement - is a peculiar information virus, which embeds into our consciousness (or sub consciousness) behavioral stereotype and semantic clichés, even during sleep. Among various types of influence there is a need to highlight neuro-linguistic programming.

Neurolinguistic programming deals with issues caused by language due to programming of mental processes and other functions of nervous system and also studies how psychological processes and nervous system form our language and are reflected in it." [7]

Methods of neurolinguistics programming were developed by CIA specialists precisely in order to be able to subdue individual's will, impose certain point of view, urge to make certain actions through innocent on first glance (more specifically - sound) words.

"Nervous system, responsible for creation of representative linguistic system, is the same nervous system which helps people to build all other models of the universe - visual, kinesthetic etc. These systems have the same structural principles." [8]

Simplest examples of NLP

Example 1:

Mother enters the bathroom and sees her 3-year old child putting an open blade into his mouth. Instantly mother realized that any incautious sharp move will result in child being hurt. She smiled at the children and quietly started praising the boy what a wonderful "toy" he has in his mouth while slowly moving towards him. The child under the "spell" froze with the blade in the mouth until mother approached her and was able to take away the dangerous item. This example shows how the woman with her tone quality and manipulating the volume of her voice confident, yet soft, moving slowly, made the child to freeze.

Example 2:

17-year old boy who was rejected by a girl decided to commit suicide. He is standing at the top of a 14-storied building and plans to jump. His loved ones are crying and trying to persuade the boy to live, but this only adds him confidence and fervor for suicide in front of numerous spectators. The group is joined by a 
neighbor, who is a qualified psychologist. He begins to excitedly encourage the boy to jump, describing in detail how he would crush against the ground and which bones would be shattered. Terrified "hero" climbs down the barrier wall. This example shows how verbally illustrating the future and pretended confidence of the psychologist make the boy change his mind about committing suicide.

Example 3:

Sportsman pole vaulting after a complex trauma is afraid to and refuses to jump. Trainer is inspiring the sportsman. He confidently makes him to try again and believe in his positive result. Active encouragement: "You can do it!" compels the boy to action and he makes it over bar. Here we can see how confident strength of words helps to overcome the fear.

So, as we can see, the mother, psychologist and trainer as a result of active, confident action with words, with help of lowering or raising their voice created necessary atmosphere and achieved the desired result, therefore, have compelled another person to act in line with the proposed option. However, unlike the adults, child understands better images than words.

"Research has shown that watching TV programs, which contain scenes of violence cause children to act violently. Such children are more frequently committing delinquencies than children, who are not into such programs. Also there is a relation that watching action movies in the age of 7-8 years old may cause increase of aggression at the age of 17-19 years old." [8]

Watching the hero of the action movie the child dreams to be like the favorite character and consciously or subconsciously begins to copy him. We increasingly see on the news stories that remind us of scary stories of our childhood ("Children were playing to be Gestapo, brutally tortured was plumber Potapov").

Based on observations of Russian psychologists, horror movies fans having unstable psyche and are more prone to diseases, than those who care less about horror stories on TV. "People and children, who frequently watch detectives, action movies or thrillers, are often prone to groundless fears, fearing that they can be attacked etc." [8] By copying the behavior of movie and TV heroes the child copies their language and behavior style.

Modern television, due to lack of air time, unprofessional editorial staff with its language style increasingly reminds Teletubbies (BBC-produced, broadcasted at the New Channel in Ukraine). Authors of these huge stupidly-happy characters probably acted according to the principle "Raise your audience!". Unwitting viewer will be excited even about one smart word, and two smart words would be beyond his understanding!

TV channels policies aimed at explaining to "unwitting viewers" of diverse, misbalanced and onesided information, therefore programming them for respective actions. A person, who was "fed" with information from childhood stops to get the essence of information.

Robert Dilts in his book "Focus of speech" described how by changing conjunctions in the sentence one aspects are prioritized, while others serve as their background. Let's review conjunctions "however", "but", "and", "even if". When we express our ideas or emotions using them, words make us focus on diverse aspects of the same feelings. Phrase "Today there is sunshine, however it will rain tomorrow" makes us concerned about the next day, at the same time we practically do not take into account that today there is sunshine. If these statements are linked with the word "but", the emphasis is made equally on 2 events. If we say: "Today there is sunshine, even though it rains tomorrow", all our attention will focus on the first statement and the second part will remain in the background". [4, 96]

Hence, we see that the conjunction "but" gives the sentence negative connotation, while the conjunction "even though" gives wish to live and enjoy sunshine.

Common instrument of influence used in advertising - "shift" of attention from Problem to result. Let's compare psychological indicators of result and problem.

\begin{tabular}{|l|l|}
\hline \multicolumn{1}{|c|}{ Result } & \multicolumn{1}{|c|}{ Problem } \\
\hline $\begin{array}{l}\text { What do you want? How to achieve this? What is } \\
\text { required for this? }\end{array}$ & $\begin{array}{l}\text { What is the source of the problem? What is the prob- } \\
\text { lem? Why is this a problem? What caused it? Whose } \\
\text { fault is that? }\end{array}$ \\
\hline
\end{tabular}

Example of advertisement: "I started to wash my face with Dove soap and my face looks perfect now. Skin does not dry out. You also deserve better!"

Problem: "I do not look good? Why? Because face skin is dry! Why should I do? I want to look perfect! Perhaps I should change the soap?"

Shift of attention towards result - allows to look at the problem of dry face skin more optimistically and gives hope that all similarities to Cindy Crawford can be provided just with a piece of soap!

Television is a cheap and convenient means of leisure. In the average home TV is turned on 7-8 hours per day. Largest portion of time near TV is spent by the elderly and pre-school children.

"A survey was conducted among American jail inmates - can TV teach you new criminal tricks, 8 of 10 responded positively, 3 out of 10 said that they tried to commit a crime, being led by what they saw". [6]

However, TV should not be seen only as a negative impact factor. 
"Wisely organized, created with taking into account of its impact on human being, television may bring good influence both for mental and physical health. In ancient Egypt color was used for healing. Color therapy, once widely used in the East, receive a revival today. When series of TV programs is created with account of how color affects people, diverse range of colors can have a positive impact on viewer" $[3,76]$

Russian sociologist Andriy Bezsmertniy in his article "Cinema and Art" considers that the blue screen is the "healer of souls" and calls movies "magic lord", which destroys various taboos and can help our society to become more liberated and healthier, to facilitate the releasing from old phantoms and horrors ... Complexes and affects are taken out of the psyche of the viewers with the help of different movie genres. Horror movies free sub-consciousness from the fear of death or disease, comedy takes away the conflict between society and individual; passion of a detective story lies not only in the romance of a big city, but also in emphasizing the right of each person to protection." [2]

It is noteworthy that above movie genres have to be offered to young viewer with caution, who is unlikely to need "therapy" with horror movie and stress caused by exposure to violence may lead to mental disorders.

Movies and TV programs for children can facilitate intellectual development of young TV viewers. The development, however, depends of the content and genre of TV programs.

Positive animated cartoons, with good idea and quality, educational programs with stimulating content have good impact on children of pre-school age, as during this period knowledge of language is actively formed. Positive entertainment programs for children can facilitate further development of intellectual capacity of very little kids, as children in this age are extremely sensitive and acquire the information flow streaming from everywhere.

This sensitivity becomes lower with age, but stable habits to watching certain programs are formed during first 2-3 years of life.

Practical issues related to applying television in middle schools and high schools were reflected in the works of such researchers as B. Firsov, T. Shabalina, A. Gelmot, S. Shapovalenko and others, as well as thesis of O.R. Samartsev, L.G. Vostokova, A. L. Golub, L. A. Guseva.

"Today systemic and structural changes in education are required. They are dictated by the avalanche increase of the information flow. It has been calculated, that during the past 10-15 years, the volume of information accumulated by humanity during the time of its existence has increased twofold, and starting with 2010 such twofold increase will be observed twice a year." [5]

The main task of educational television is to encourage the child to strive for knowledge and to encourage to learn.

"European states have over 300 educational programs: news, entertaining and directly educational, which include all age groups of students." [5]

European museum administrations cooperate with TV channels in preparation of the programs, periodically sending their own comments on a particular program. British channels BBBC Knowledge is satellite broadcasting orienting itself on the audience that almost exclusively consists of college graduates, students and teachers. In the USA 9 largest TV networks are engaged in production of educational programs, this does not take into account local TV programs and university TV centers. National aerospace agency and Academy of Pediatrics also participate in the production of such programs. Broadcasting is done almost 24/7: educational TV shows, interactive quizzes, entertainment films, movies and films about art. [6]

There are over 800 educational TV channels in the USA. Different shows of educational nature are common, as well as historical and geographical films.

Japan has one main educational TV channel-state TV company NHK and 35 local TV stations. There is national educational TV network. Educational programs represent on of the main directions of Japanese TV space. The most well-known educational projects are represented by studios Akita - JOUK 2 NHK, Aomory - JOTC 5 NHK, Nagano - JONB 9 NHK, Osaka -JOBB 12 NHK, Matsue - JOTB 12 NHK.

Australia, Canada, Cuba, Denmark, Finland, Israel, Netherlands, New Zealand, South African Republic, and Switzerland have their own educational channels. Scientific, educational and cultural centers, libraries and professional associations take part in creation of educational block. [5]

Modern Ukrainian educational TV space is in the nascent stage. Programs for children and youth do not have a defined age group orientation and their level is below ordinary. There are no special programs for children, who do not see well or are deaf-mute. I believe that TV channels have to clearly divide the air time between programs for children and youth and programs for adults. First half of the day should be set aside for cartoons, movies for children, popular scientific programs. During this time there should be no space for advertisements and video clips. As in the morning audience consists mainly of preschoolers and elderly, and technical components of this type of products is equally harmful for them. [10]

School news for teenage audience are absent from the national TV space. There is no practice of school TV that would specialize on production of programs by students for their own school. Modern Ukrainian television has completely lost its educational function. The air is oversaturated with negative messages. Idea of information programs comes down to one point: "If you have money - you are a respected person and can get away with anything, if you donot - you will end up being a scapegoat!" Patriotic programs in their sense become mourning sagas. 
Elderly, without a cent of funds, sick veterans of various wars cause sympathy, but not the wish to follow their example. That's why modern teenagers believe in American happy end, in cyber robots and Ninja turtles, who happily fight and argue living in the sewage outlets. We forget that television is an important and necessary instrument of propaganda. Competing for audience, modern Ukrainian TV channels are gradually destroying national and moral consciousness of this audience.

It is equally important to pay attention towards such vulnerable group as people living with disabilities. A separate channel would be needed for people with vision and hearing problems, especially if they are children. Programs for this channel should be narrative and descriptive; video should be not to bright, duration of one frame should not exceed 4 seconds. Presenters should have a pleasant voice and especially distinct articulation; text should be also repeated by a signer. The child with physical disabilities spends more time at home, which means more time in front of the screen. Therefore, it is needed to create certain conditions for these children to be able to watch TV programs.

Conclusions. Television is an important and necessary instrument of building of our country. Tomorrow's future - is a small viewer today, his world-view will largely depend from the daily information flow reaching him from the blue screen.

\section{תimepamypa}

1. Ананьев Б.Г. Человек как предмет познания. СПБ. : Питер, 2001. 288 с .

2. Безсмертный А. Кино и общество. URL: http://www.ovsem.com/user/kinoo. (дата звернення 14.09.2018)

3. Дайджест статей. Москва : Искусство, 1988. 255 с.

4. Dilts Robert. Foci of the language. Change beliefs with NLP. PH -Piter, 2012. $256 \mathrm{p}$.

5. Интернет издание «Политическая азбука для ЛДПР» URL: http://www.Idpr.ru/Azbuka/azbuka_televid.htm (дата звернення 14.10.018)

6. Lippman W. Public Opinion. Millan Company. 1926. 198 p.

7. Основные принципы НЛП. Применение НЛП в воспитании дошкольников.

URL: https://works.doklad.ru/view/LH4rC7iNbeA/all.html (дата звернення 12.11. 2017)

8. Психологические последствия влияния телевидения на детей. URL: http://www.enpsy.ru/publications/childtv.htm (дата звернення 14.10.2018)

9. Самарцев Р. Телевидение в системе образования: автореферат дисс. ... филологии. Москва. 1995. $125 \mathrm{c}$.

10. Українське телебачення: роки, події, звершення.К. : Дирекція ФВД, 2008. 400 с.

11. Усенко Ю.В. Становлення та розвиток українського телебачення як засобу масової комунікації: автореферат дис. ... канд. іст. наук : 17.00.01. К: КНУКіМ, 2006. 20 с.

12. Ядов В. А. Саморегуляция и прогнозирование социального поведения личности. Л.: Наука, 1979. 264

c.

13. Вебсайт о покемонах. URL: http://pokemoni.boom.ru/debil.html (дата звернення 11.10.2018)

\section{References}

1. Ananyev, B. G. (2001). Human as a subject of knowledge. SPb.: Piter [in Russian].

2. Bezsmertniy A. Cinema and Society. URL: https://psyfactor.org/kinoprop/kino3.htm. [in Russian].

3. Digest of articles. (1988). Moscow: Art [in Russian].

4. Dilts Robert. (2012). Foci of the language. Change beliefs with NLP. - PH -Piter [in English].

5. Internet outlet «Political ABC for LDPR». URL: http://www.Idpr.ru/Azbuka/azbuka_televid.htm [in Russian].

6. Lippman, W. (1926) Public Opinion. New York: Millan Company [in English].

7. Main principles of NLP. Application of NLP in the education of preschool children.

URL: https://works.doklad.ru/view/LH4rC7iNbeA/all.html, [in Russian].
8. Psychological
consequences
on
television
influence
on children.
URL:

http://www.enpsy.ru/publications/childtv.htm [in Russian].

9. Samartsev, R. (1995) Television in the system of education. Thesis synopsis for the scientific degree in the field of philology. Moscow [in Russian].

10. Ukrainian TV: years, events, accomplishments. (2008). K.: Directorate of FVD [in Ukrainian].

11. Usenko, Y. V. (2006). Establishment and development of Ukrainian television as instrument for mass communication. Extended abstract of candidate's thesis. Kyiv: KNUK\&A [in Ukrainian].

12. Yadov, V. A. (1979). Self-regulation and prognosis of social behaviour of an individual. Study. L.: Nauka [in Russian].

13. Website of pokemones. URL: http://pokemoni.boom.ru/debil.html [in Russian].

Стаття надійшла до редакції 28.10.2018 p. 